\title{
Linguistic variation and the construction of social identity in a German-Turkish setting
}

\section{A case study of an immigrant youth group in Mannheim, Germany}

\author{
Werner Kallmeyer and Inken Keim \\ Institut für Deutsche Sprache Mannheim
}

\section{Introduction: research context and aim of the study}

The analysis which we present in this paper is part of an ethnographically based sociolinguistic study of various immigrant youth groups and their social style of communication. ${ }^{1}$ The study describes the wide variety of migrant groups and their socio-cultural orientation in relation to different migrant worlds as well as to different social worlds of the dominant German society. The development of a social style of communication is grounded in the groups' socio-cultural orientation as well as in the perception of themselves in relation to relevant others. The main purpose of our study is to analyse the construction of the groups' social identity in terms of their social style of communication. ${ }^{2}$

Our study uses ethnographic interviews and participant observation. The data collection consists of audio-recordings of ethnographic interviews, ethnographic records (field notes, photographs), and of audio- and video-recordings of natural conversations. The conversational data are analysed with conversation-analytic and sociolinguistic methods.

Our concept of social style is influenced by the anthropological and ethnographic concepts of cultural style, where style is related to a groups' culture and its social identity. ${ }^{3}$ In this tradition, cultural style is the product of the adjustment of human communities to their ecological, social, and economical conditions. Part of these conditions is the striving for social equality and for social integration and differentiation. Cultural or social styles correspond with the schematic knowledge of social behavior, and their relevant traits reflect distinctive features of the respective cultural paradigm. In this respect, a social style has a fundamentally strategic grounding, and it is defined as the specific cultural solution for existential needs. The 
specific characteristics of a cultural style become obvious through a comparison across different social worlds. Practices of linguistic variation, as described in linguistic and sociolinguistic stylistics, are constitutive of our concept of social style together with other aspects of communicative expression.

Style is a holistic concept. Members' ideas about social styles of communication are prototypically organized: they are constructed around key phenomena, and they have fuzzy boundaries. The construction of a communicative social style is connected with the formation of specific linguistic and communicative patterns and rules on different linguistic levels. Elements from all expressive levels are combined to form a unique expression means. This is a dynamic process: new materials can be incorporated so as to result in different stades of stylistic density.

On the basis of sociolinguistic and ethnographic research results, ${ }^{4}$ we assume that the following dimensions of expressive behavior are essential for the construction of a social style: pragmatic rules of speaking, especially rules for the regulation of social distance; the construction of systems of social categories for defining group members and outsiders and the procedures for contextualizing social categories; specific verbal and nonverbal aesthetic means; formulaic speech for the handling of specific communicative problems; linguistic variation for purposes of interactional organization and for socio-symbolic reasons. In this chapter, we will focus on some of these dimensions, namely, linguistic variation practices, and their relation to specific pragmatic rules and to social categorization.

\section{Profile of the immigrant youth group under investigation}

Our ethnographic research has been carried out in a district of the inner city of Mannheim, an industrial town of 320000 inhabitants in south-western Germany, situated near Heidelberg. Over $20 \%$ of Mannheim's population comprise ethnic minorities, most of them of Turkish origin. In the inner city, some districts have over $60 \%$ of population from ethnic minorities. Our ethnographic research has in fact been carried out in one of these districts, a traditional working class district.

In this district, there are no ethnically homogeneous youth groups, even though the majority of the group members are of Turkish origin. Most youth groups are single-sex; there are stable girl- and boy-groups, and most of them meet in the district's youth centers. The group that we will present here is a group of about 15 girls who meet almost daily in one of the youth centers. There, they work together on their school homework; they play games, smoke, listen to music, or dance. The girls are between 15 and 21 years old; most of them are of Turkish origin, two of Italian, one African (from Ghana), one Bosnian, and one Thai. The girls' parents came to Germany in the 60 s as guestworkers. Most of the parents still speak the 
typical "guestworker's German" ("Gastarbeiterdeutsch"), a pidginized German variety ${ }^{5}$ spoken by the first migrant generation, and some of the mothers speak almost no German at all. Most of the girls go to the Haupt- and Realschule (i.e., schools for lower and middle education), some to the Gymnasium. All girls were born in Germany and grew up in the district. The girls' social networks and their socio-cultural orientation are limited to the social life of the district. From the perspective of the German social worker in the youth center, one of the girls' main characteristics is their "toughness"; they are characterized as "rough and cool", and their form of verbal communication within the group is called "district talk" ("Stadtteilsprache") or "gangster jargon".

According to our observations, the girls' linguistic repertoire contains, on the one hand, some kind of dialectal variety of their country of origin, that is, in most cases a Turkish or Italian variety which, according to Turkish and Italian experts, has considerable structural and lexical influence from German standard and the local urban dialect ("Mannheimerisch"). On the other hand, the girls' repertoire contains several German and language mixing varieties, especially:

- the German variety learned at the German school, which corresponds to nearstandard German with local influences; this variety is often used in contact with adults, teachers, instructors, and social-workers;

- a German-Turkish language mixture used among girls of Turkish origin with numerous code-switchings and integrated German-Turkish constructions;

- a variety used as a medium of communication between youngsters of different cultural and linguistic origin, the "district talk" ("Stadtteilsprache"); this is a simplified version of a German colloquial variety with special rules of speaking and with a sometimes pidginized morphosyntax, especially with deletion of prepositions and articles: ich geh doktor (I go doctor) or wo kommst $d u$ (where do you come). In all these varieties, the girls have varying degrees of active competence.

Besides these varieties, the girls use forms of the Mannheim dialect and forms of the "Gastarbeiterdeutsch" (guestworkers' German) for caricature and ridicule of specific social categories. Specifically, the girls use guestworkers' German for the caricature of the "uninformed and uneducated guestworker" who has historically come from rural regions of southern countries and has worked as an unskilled worker in Germany. 


\section{Linguistic variation in in-group communication between girls of Turkish origin}

In in-group situations, when talking to one another, the girls of Turkish origin often use a German-Turkish language mixture even in the presence of members with another linguistic background. Depending upon the partner, the context, and the topic of communication, this in-group variety presents phases, where one of the languages, German or Turkish, can be described as the matrix language with many cases of transfer (e.g., borrowed terms, formulas, formulaic expressions, proverbs) from German or Turkish, respectively. These transfers are clearly marked as insertions or code-switchings, prosodically, phonetically, and lexically. Such clearly marked cases of language variation, where from one point onwards a speaker changes the language or where a clearly contrasting construction from another language is inserted into a matrix language, could be described with code-switching models." In these cases, one language plays the dominant and the other a subordinate role.?

But there are numerous cases when speakers choose one language and then the other without assigning dominant status to either one, and complex mixed constructions with varying patterns recur. ${ }^{8}$ In these language mixing phases, phonetic, lexical, or syntactical elements of the used varieties are smoothly interrelated; ${ }^{9}$ there is no prosodic break between elements of different languages, sometimes not even a clear phonetic contrast. The emerging mode of communication could be characterized as an "integrated language mixture" (our term).

This mixing variation is patterned and serves various structural and interactional purposes. To analyse these, we need to follow recent studies on linguistic variation and code-switching which focus on the intertwining and mixing of different codes, to abandon some of the former general assumptions about the regularities of code-switching, and to proceed with refined structural descriptions. Interestingly, the rich literature on code-switching since the early 80 s has shifted from the description of classic code-switching with a contextually established matrix language and clearcut boundaries of the inserted stretch of another code towards the analysis of less marked and grammatically more central combinations and recurrently changing matrix languages with only a short life span producing an ambivalence of the matrix language. ${ }^{10}$

In our analysis of language variation, we speak of variation practices, where elements of one language are locally combined with elements of the other. The term "variation practices" applies to cases where a matrix language is discernable as well as to cases with language mixing. This language mixing is an essential part of the group's communicative social style; its characteristics are regular, unmarked, and fast produced turn-intern switches. These switches range from con- 
structions with "loose" grammatical connections between elements of the two languages to morphosyntactically integrated constructions. In the following example peripheral elements such as interjections, German mann (guy) and Turkish lan (guy), are used as contrasts in a Turkish and German context respectively. Two girls are playing tavla: ${ }^{\prime \prime}$

01 NA: baksana orda bir-acık kapt var ya: * mann bir acık vuramadım [ look there is a gap hey guy I have not hit one ]

02 GL: sch will mit dir spielen lan

[ I want to play with you guy]

Both interjections are very common in the district talk. German youngsters use the expression lan talk ("Lansprache") as another name for the district talk.

The next example shows a morphosyntactically integrated construction of German and Turkish elements in a specific pattern: German VERB in infinitive + inflected turkish yapmak / etmek (to do). This seems to be a widespread pattern and not only for German-Turkish language contact. ${ }^{12}$ In Turkish, the verbs etmek / yapmak can be combined with nouns and adjectives only. In the observed mixed variety, they are combined with German uninflected verbs. This constitutes an expansion of the Turkish grammatical pattern. In the following example, the German verb feiern (to celebrate) is combined with an inflected form of the Turkish yapmak and etmek:

BE: ben feiern yapmiycam $k i$ * ama feiern etmiyorum $k i$

[ I will not celebrate my birthday but I do not celebrate ]

Integrated mixing is characterized by a balanced use of elements of both languages and their grammatical interrelation. In the following example, the pattern of the former example is combined with Turkish and German phrases:

$01 \mathrm{BE}:$ hele $\uparrow^{*}$ Riff $i$ simdi bi vergessen et für ne zeitlang

[ well just forget Riff for some time ]

02 BI: ben Riffe gitmek istediğimi

[that I want to go to Riff]

After the Turkish discourse marker hele (well), the turn continues in Turkish, and the German verb vergessen (forget) is integrated in the Turkish etmek-construction. Turkish seems to be the matrix language. Yet in the second part of the turn, German elements predominate on the basis of two variation practices. Then, the second speaker starts up with Turkish; this again could signal a tendency towards Turkish as the dominant language. However, the second speaker formulates a rejection, and she may be heard using a specific variation practice which is rather recurrent in our data: opposing views of following speakers are produced in the language contrast- 
ing to first speaker's end of turn. Following this practice, in our case, the second speaker has to use Turkish in contrast to the first speaker's end of turn in German. This example shows the difficulty with analytical concepts such as matrix language or dominant language, especially in cases where different variation practices could overlap. (See also section 4.2.).

\section{Discourse functions of variation practices}

As the examples above already show, linguistic variation can function as a device for the segmentation of structural parts in a complex utterance: it can mark the difference between background and foreground information, between a proposition and the reason given for it, or between a formulation and its reformulation. But in many cases, just like the switching between utterances, this utterance structuring switching has aditional functions, too. Variation practices can serve very different discourse functions. Code-switching is often used for marking topic change or the return to an already established topic after interruptions or side activities. An important field of interactional functions is the regulation of participation roles, and another one is the management of consensus or dissent in arguments by linguistic convergence or divergence.

\subsection{Linguistic variation as a device for interactional organization}

A switch of language from German to Turkish and vice versa can function as a device for the selection of the next interactional partner or for the constitution of a new interactional constellation. This kind of language switch was first described as situational code-switching (Blom / Gumperz 1972). Besides that, the language of interaction can be changed, for example, in order to display that a new participant with a known linguistic competence or a specific language preference will come into play. Alternatively, the use of Turkish in contrast to German can help separate parallel interactions. Furthermore, a switch of language can function as a device for getting or keeping the floor.

The following example illustrates some aspects of the often highly complex functioning of language switching for interactional organization. A couple of girls are in the locker room of the sports grounds with their trainer Corinna, a German social worker. Some of the girls have already changed clothes and are leaving. Gülsen starts with an utterance in Turkish: 
01 GL: gidelim $\uparrow$ * tschüss Corinna

[ let's go bye Corinna ]

02 BE:

tschüss Corinna

[bye Corinna ]

03 HA:

ya beni beklesenize $\downarrow$ *

[wait for me ]

04 HA: ne kadar gıcıksınız * hallo" könnt ihr nich kurz warten isch hab auch so was/ [you are stupid hey can't you wait a while I too have some/]

The language choice in Gülsen's first turn is part of the recipient design: Gülsen includes the present Turkish girls, her friend Behiye, and her sister Hatçe, and she excludes all the others of non-Turkish origin. After a short pause, she switches to German with the colloquial farewell formula tschüss and adresses Corinna. In the next turn (02), Behiye too says good bye to Corinna with the same formula. With that, Behiye establishes herself as the recipient of Gülsen's first turn (gideline $\uparrow$ ) and ratifies her request. Then Hatçe comes in with the request: ya beni beklesenize (wait for me, 03). The use of Turkish signals that only her sister Gülsen and Behiye are addressed, and that all the others are excluded from the interaction between the three girls. After a short pause, Hatçe continues in Turkish with an insult ne kadar gicıksınız (you are stupid, 04); this implies that the adressees did not react to her request and did not wait for her. After another short pause, she reformulates her request in German: hallo" könnt ihr nich kurz warten (hey can't you wait a while, 04). This switch serves several functions: Hatçe reinforces her request, enlarges her audience, and draws all the participants' attention to the conflict between herself and the other two girls. Making the conflict public, she reinforces the social pressure on the two girls and makes it harder for them to ignore her request. In this example, code-switching functions as an utterance structuring device, differentiating between an utterance and its reformulation, as well as a means for structuring the social situation, excluding from or including interactional partners into the locally produced interaction.

\subsection{Linguistic variation as a device for topical organization in discourse}

One of the most striking functions in relation to topical organization in discourse is the reinforcement of consensual or controversial speaker reactions by using the first speaker's language or, respectively, a contrasting one. In the following example, some of these devices will be demonstrated.

In integrated mixing, turn-taking plays an important role for different variation practices. By using the same language or language mixture that the first speaker used at the end of his turn, the second speaker signals consent and ratification of the 
first speaker's activity. Then, the turn-taking pattern is: A: Turkish - B: Turkish or: A: German/Turkish - B: Turkish/German or: A: Turkish/German - B: German/ Turkish. This will be demonstrated in the following example: Two sisters, Hatçe and Gülsen, discuss who should go to the doctor with their little sister Şükrüye:

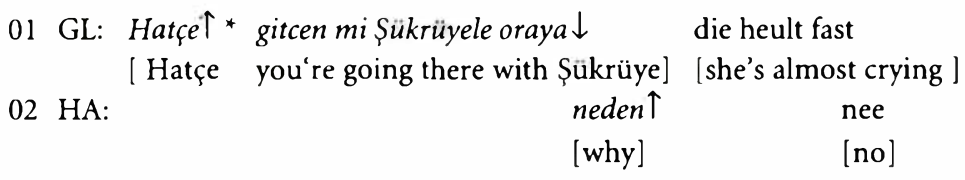

Gülsen asks her sister Hatçe in Turkish to go to the doctor with Șükrüye. Hatçe does not answer right away; in an insert sequence, she asks for reasons: neden (why), thereby taking up the chosen variety of Turkish. After that, Gülsen switches to German giving reasons why Hatçe should go with their little sister: die heult fast (she's almost crying). This language shift can be interpreted as a device for the differentiation between a proposition or an activity and giving reasons for it. Here, this pattern is performed interactively, the question following the language choice of the prior turn. In the fourth turn, Hatçe gives the answer to Gülsen's request: nee (no). Hatçe's use of German can be interpreted with reference to two different variation practices: (1) She follows again Gülsen's language choice, in accordance with the general variation pattern of convergence: the second speaker follows the first speaker's language choice. (2) Hatçe's use of German establishes a contrast to Gülsen's initial request in Turkish and reinforces Hatçe's opposition to Gülsen. This contrastive language choice which supports her rejection nee (no) to Gülsen's request follows the general variation practice of divergence: opposing views or arguments in discourse are produced in contrasting varieties. Interpreted in this way, this short sequence reveals some of the artfully and systematically used variation practices in the group's mixed variety and the interrelation of different variation practices.

The argument between the two sisters continues for a few more minutes: Hatçe is doing her school homework, and she is reading aloud a German text. Her sister Gülsen interrupts, and addresses her returning to the already established topic: She wants Hatçe to go home because their little sister is waiting for Hatçe who should take her to the doctor:

01 HA: das jahr- (...) wird als bewegung des modernen (...) [the year (...) is (understood) being the movement of the modern ]

02 GL:

Hatce $\downarrow$ ağlıyo [Hatçe I tell ] 
03 GL: evde diyorum sana

[I tell you she's crying at home]
$<$ ja: $>$ du sollst

[yes you should-]
$<+$ mir ega"l mann $\downarrow>$

[I don't care man]
(......) lü“g nicht Hatçe

[don't lie Hatçe ]

üc buçuk dedi

[she said half past four]

05 HA: vallahi üç buçuk dedi

halt $=\mathbf{s}$ maul

[ I swear she said half past four]

[shut up ]

06 GL:

geb net an

[don't show off ]

Gülsen addresses Hatçe and reminds her of their crying little sister. For this, she uses Turkish in contrast to Hatçe's homework performance in German. By switching to Turkish, she reinforces her point, her interruption of Hatçe's actual activity, and the restart of the controversial topic. Hatçe rejects Gülsen's request by switching to German: mir ega"l mann (I don't care man, 04), thereby, marking the opposition to her sister's request. Starting with an intensified request, Gülsen takes up her sister's language choice (03) but is interrupted by Hatçe, who gives reasons for her rejection, switching to Turkish (ïc bucuk dedi, she said half past four, 04). On one hand, the switch may mark the differentiation between rejecting and giving reasons for it; on the other hand, the switch reinforces Hatçe's opposition to her sister. Till now, Hatçe exhibits linguistic divergence two times which means that she insists on disagreeing. Then, Gülsen uses the pattern of language divergence too, and both girls repeat this contrasting practice. The mutual and reiterated use of this pattern is typical of discussions with opposing arguments.

The last two turns, initiated by Hatçe, follow another pattern. They form a kind of paired ritual insult. Ritual insults are very common in the group; they are always produced in the same variety, which means that the second speaker takes up the first speaker's language choice. In our case, following the opposing-argument-pattern, Hatçe switches to German, and, in this variety, she produces the first part of a ritual insult: geb net an (don't show off, 06); Gülsen reacts with the second part of the ritual, by taking up the first part's language: halt=s maul (shut up, 05). This case examplifies the girls' natural and routinized use of various variation patterns and practices.

\section{Linguistic variation with socio-symbolic functions}

In addition to these variation practices that especially serve utterance and interaction structuring functions, there exist variation practices, where the use of elements of other varieties has socio-symbolic functions, that is, where the code used represents social properties of the speaker or others. Typical of socio-symbolic practices are code-switches, where essential linguistic features are especially marked, at times 
overdrawn in order to convey specific social meanings and to contextualize specific features of social types or categories. These practices function as a means for the symbolization of social belonging or social distance.

In order to demonstrate the sociosymbolic functions of variational practices, we will give an extended example where district talk is used in order to symbolize the tough and rude behavior which indicates ghetto membership, and where, as a consequence, the German social worker Corinna is treated as an outsider.

Before we start with the analysis, we will give a short characterization of the district talk. As already mentioned above, this is the communication medium between young people of different linguistic backgrounds. Schools, playgrounds, and youth centers of the district are the scenes for the formation of this variety. Its characteristics are:

- a simplified version of the German vernacular with deletion of prepositions and articles, generalization of some verbs like machen (to do), gehen (to go) kommen (to come), and of some adverbs like voll, krass (which function as intensifiers), and cool (as a positive evaluation),

- the use of some formulas like isch schwör (I swear),

- special prosodic and phonetic features;

- a stylization of the "Ausländerakzent" (the foreigners' accent in German);

- a special kind of information transfer which presupposes a high degree of shared knowledge and explicates only small parts of what is necessary for an interlocutor's understanding; this type of information management functions very well in in-group communication, but when used vis-à-vis outsiders, it has a provocative effect;

- specific rules of face-work, for example, with respect to attending to the addressees' negative face and their right to their personal territory;

- the demonstration of readiness for aggressive actions, expressed by nonverbal means (for example, threatening gestures and wild looks), by specific prosodic patterns (loud and rough voice, fast speach tempo with lengthening of the last syllable of an utterance), and by German or Turkish swear words and swear formulas.

To German outsiders, for example, teachers and social workers, this kind of variety sounds "rough, aggressive, and uneducated".

In the following example, the setting is again the locker room of the sports grounds. The girls are sitting and discussing the last volleyball training with their trainer Corinna. All girls who are present are Turkish except Nok, a girl of Thai origin (grown up in the district, Thai mother, German father). Nok uses elements of the district talk in the conversation with Corinna. Her behavior is implicitly and explicitly criticized by Corinna and later on by her closest friend Hatçe, a Turkish 
girl. Corinna expresses her evaluation in a playful modality, and Hatçe makes it clear that district talk is not the adequate way of speaking with Corinna. Applying linguistic marking practices, she symbolizes Nok as a rude and rough district kid. The interaction starts when, in the course of the discussion about volleyball, Nok interrupts and addresses Corinna:

01 NO: $\leftarrow$ Corinna: $\rightarrow$ mein bruder kann nich nach hause: ${ }^{*}$ die laufen hier gleich vorbei $\downarrow *$ $02 \mathrm{CO}: \quad \mathrm{hm} \uparrow$ [my brother can't go home right now they will be passing by]

03 CO: und da"nn? die solln doch klingeln [so what] [they should ring the bell ]

$04 \mathrm{NO}$ isch muss rausgehn schlüssel geben $\downarrow$ aber sie wissen [I must go out give housekey] [but they don't]

05 NO: doch nicht davon [know anything about it]

$06 \mathrm{CO}$ : $\leftarrow$ was $\downarrow \rightarrow$ * [about what]

$07 \mathrm{~K}$ $\leftarrow$ äh dass $\rightarrow$ dass isch hier bin

[that I,m here ] $\leftarrow$ wieso $\uparrow \rightarrow^{*}<$ du machst [why you arrange] HIGH VOICE

08 CO: immer=n blödes zeug aus $\downarrow$ des \#macht mich ra“send $\downarrow$ * $\leftarrow$ ni“chts is normal bei der $\downarrow$ \# [ things stupidly that drives me mad nothing is normal with her]

$09 \mathrm{~K}$ \#LAUGHING GIGGLING

$11 \mathrm{CO}: \leftarrow$ was heißt dein bruder läuft vorbei dann soll er doch vorbei"laufen $\rightarrow{ }^{*}$ der kann doch [what does it mean your brother is passing by why shouldn't he he can walk ]

$12 \mathrm{NO}$ : nei"n [no ]

13 CO: rumlaufen [ around]

wa"s hat se gesagt [what did she say]

14 NO: der wei“ $B$ nix * mein mutter hat mir gesagt- * [ he doesn't know my mother told me] dass ich denen schlü"ssel [that I should give them ]

15 NO: geben muss- * [keys ]

16 ÖZ: ja sonst kommn die nich rein [because they can't go in ]

$17 \mathrm{CO}$ : wie" das [how comes]

Nok initiates a new topic in the kind of information management that is characteristic of the district talk: mein bruder kann nich nach hause * die laufen hier gleich 
vorbei (my brother can't go home ${ }^{*}$ they will be passing by right here). There is nothing prosodic or verbal to signal that a new topic is being raised; similarly, no information is given about the topic's relevance for the addressee, Corinna. Asking back und dann $\uparrow$ (so what) Corinna signals that she cannot interpret Nok's utterance and that it has no adequate recipient design. After that Nok presents some further information in a pidginized form (deletion of article and pronoun): isch muß rausgehn schlüssel geben (I must go out give housekey). Corinna reacts with an alternative suggestion: die solln doch klingeln (they should ring the bell). From her point of view, and without the background knowledge that is presupposed in Nok's utterance, this is a plausible suggestion: Corinna does not want Nok to leave the sports grounds because the training is starting in a few minutes. But Nok rejects this suggestion aber die wissen doch nichts davon (but they don't know anything about it), signaling that her problem is quite complicated. But the kind of complication is not yet obvious to Corinna, and she asks again: was $\downarrow$ (about what). After that Nok provides more information: dass ich hier bin (that I'm here, they don't know it.).

Nok's way of telling her problem forces the adressee to produce the relevant elements of information interactively. Without considering the partner's missing background knowledge, Nok presents her complex case as a kind of puzzle, making little effort to facilitate understanding for the partner. Corinna has to ask for further information, and Nok presents only as much information as is necessary for Corinna's next question in order to solve the puzzle. When - probably too early in the sequential process of this kind of information management - Corinna makes a suggestion for an alternative solution to Nok's problem, Nok points out that she is on the wrong path for the puzzle solution, and she corrects her.

The problem Nok is talking about is this: Her little brothers do not have housekeys; on their routine way home from the kindergarden, they pass the sports grounds at a specific time; since they do not know that their sister, who has the keys, is on the sports grounds, she has to leave the grounds and meet them on their way home in order to give them the keys. But leaving the sports grounds means missing the beginning of the volleyball training, and she has to ask for Corinna's permission to leave the grounds.

This kind of information management may be influenced by the girl's cultural background, but other kids of the district with different backgrounds know this style too. The girls of the group understand right away what Nok wants to say and one of them, Özlem (ÖZ) fills in the missing links, even though she does not have the information about Nok's actual arrangement: ja sonst kommn die nich rein (because they can't go in).

After Corinna's explicit and playfully modulated comment on Nok's behavior: du machst immer en blödes zeug aus $\downarrow$ des macht mich rasend $\downarrow$ ni" chts is normal bei der $\downarrow$ (you arrange things stupidly; that drives me mad; nothing is normal with her, 
06-08), where she criticizes Nok's lack of organisational skills and her way of imparting information, Hatçe, Nok's friend, also reprimands her:

18 HA: erzähl doch mal geschei"t lan $\downarrow$ die mutter is di"ng äh* sie muss geschäftlich was tun $\uparrow$ [hey guy why don't you tell her decently the mother had to go out to arrange things ]

19 HA: die is gegangen ja $\downarrow$ hat derre gesagt wenn äh * Nei und Andreas vorbeigehn * [she went away told her when Nei and Andreas are passing by ]

20 HA: dann gib denen den schlüssel $\downarrow$ * [then you should give them the key]

21 NO:

$22 \mathrm{CO}$ genau $\downarrow$ [exactly ]
$<$ la"n die laufen

[hey guy they're ]

$$
\begin{aligned}
& \text { wie“ vorbeigehn } \downarrow \\
& \text { [what does it mean passing by ] }
\end{aligned}
$$

23 HA: doch vom ding äb/ ${ }^{*} 2^{*} \rightarrow$ tschuldigung $\leftarrow$ * die laufen doch vom hort äh nach hause [coming from äh] [excuse me they're coming from kindergarten and they're]

24 ÖZ: $\underline{\operatorname{lan} \uparrow}$ [hey guy ]

$25 \mathrm{~K}$

LAUGHING

Hatçe reprimands Nok for her kind of narrative presentation: erzähl doch mal gescheit lan (hey guy why don't you tell her decently, 18). From Hatçe's point of view, Nok's mode of presentation is not adequate in the conversation with Corinna. Then Hatçe keeps the turn, speaks instead of Nok and presents Nok's case chronologically (18-20). Again, Corinna comes in with her questioning tactic, even though she could have made the necessary inferences now (22). She overdoes her former questioning tactic and uses every opportunity to ask for further information signaling that she is not ready to make any necessary inferences.

In response to Corinna's overdoing the questioning, Hatçe gets impatient. In a louder voice and by clearly marking the switch in variety, she says: lan $\uparrow$ die laufen doch vom ding äyh (hey guy they are coming from, 20-23). The switch is marked by the address form lan, for which Hatçe is at once reprimanded by Özlem lan $\uparrow$ (24), and she apologizes right away tschuldigung (excuse me, 23). The address form lan (chap, guy) is one of the most striking characteristics of the district talk. With the reprimand and the apology — both very routinely produced - it becomes evident that the girls distinguish between the district talk and a kind of talk that is adequate in conversation with Corinna.

Some time later towards the end of the training, the distinction between these two styles is once again clearly expressed, and Nok is again criticized for the inadequate use of district talk vis-à-vis Corinna. Nok has to leave the training earlier; therefore, she rejects Corinna's command to help clearing up after the training: 
01 NO: nei" $n$ Corinna ich hab aber keine zeit $\leftarrow$ ich muss bahnhof geh:n $\rightarrow$ [ no Corinna I have no time I must go station ]

02 HA: $\rightarrow$ die kann nich [she can,t]

03 HA: die kann nich $\leftarrow$ die muss $<\leftarrow$ bah"nhof geh:n $\rightarrow>$ * die muss $<\leftarrow$ bah" "nhof geh::n $\rightarrow>$ [she can't she must go station she must go station ]

Nok protests with: nein Corinna ich hab keine zeit $\leftarrow$ ich muß bah" nhof geh: $n \rightarrow$ (no Corinna I have no time I must go station, 01). The last segment has characteristics of the district talk: deletion of article and preposition. In the next turn, her friend Hatçe ridicules Nok's use of district talk elements; she reformulates Nok's utterance with a shrieking voice combined with the lengthening of the last syllable, that is produced in a very marked way: die kann nich die kann nich die muss $<\leftarrow$ bah" nhof geh:: $n \rightarrow>$ (she can't she can't she must go station, 02-03). This way of speaking has the quality of caricature signaled by the exaggeration of salient features of district talk. Here, Hatçe demonstrates that there are two ways of speaking, that she knows, and that she is able to produce. She attributes district talk to her friend Nok, and she criticizes her by ridiculing the use of this talk vis-à-vis Corinna. ${ }^{13}$ District talk is presented as a simple, rough, and rude way of speaking. It thus functions as a means for the socio-symbolic categorization of Nok as a rough und rude district kid vis-àvis Corinna. In addition, the clear differentiation between the two ways of speaking and the attribution of only one way of speaking as the adequate mode vis-à-vis Corinna functions as a means for the sociosymbolic categorization of Corinna as an outsider of the group.

\section{Linguistic variation and social style of communication}

As these examples demonstrate, the group's variation practices are manifold and could not be described with one of the known variation concepts. On the contrary, they cover the entire field of variation typology. What is characteristic of their communication is the high variability, the forms of combining different variation patterns, and the density of their use. The types of various practices which the girls use reflect different aspects of their complex social situation, living with two or more languages and in two cultures and not totally identifying with one or the other. For the girls' self-positioning in these complex social surroundings, three aspects are essential: (1) the cultural distance to the parents' generation and their social and cultural orientations especially in relation to women's education; (2) the distance to the dominant adult German society which confronts them with overt or hidden discrimination, and (3) the reaction to the styles of other youth groups 
which follow alternative orientations in relation to the social world of foreigners (which they perceive as "the ghetto") and the possible integration into the German society. The influence of these three aspects converges in the girls' orientation to self-determination, freedom of movement, readiness for self-defense, and a social positioning which corresponds to their specific experiences and living conditions and avoids the trap of an apparently easy integration into other-dominated social worlds. In many respects, the girls' communicative style is a typical youth cultural style. What they share with other youth groups is the playful and sometimes artistic handling of many different voices (Bakhtin 1986), the practices of provoking outsiders and defending a territory of their own. Nonetheless, their repertoire of linguistic variation and their communication patterns, as described above, mark a specific variant of (girls') youth culture which typically develops in reaction to a migrant ghetto.

\section{Transcription conventions}

The transcription uses the signs of the German alphabet in analogy to the rules of pronunciation in German for the representation of the phonological and phonetic features of the spoken language, including dialectal speech. In addition, we use the following notation:

$\begin{array}{ll}*, * * & \text { short pause, longer pause } \\ \uparrow, \downarrow,- & \text { rising, falling and middle intonation } \\ \leftarrow, \rightarrow & \text { slower, faster tempo } \\ <,> & \text { louder, softer voice } \\ “ & \text { strong accent } \\ : & \text { lengthening } \\ = & \text { slurring manner of articulation, linking different words. } \\ \text { hab ich } & \text { overlap passages } \\ \# \# & \text { extension of comments }\end{array}$

\section{Notes}

1. The project has the title "Deutsch-Türkische Sprachvariation und die Herausbildung kommunikativer Stile in dominant türkischen Migrantengruppen" ('German-Turkish language variation and the construction of speech styles in dominantly Turkish groups of migrant youth'). It is part of a research group at the University of Mannheim and the Institute for the German Language in Mannheim, which is funded by the Deutsche Forschungsgemeinschaft (see: www.ids-mannheim.de/prag/sprachvariation). 
2. We selected four youth groups, two groups at youth centers in the district, and in contrast to that two student groups at the university of Mannheim, and observed them in in-group situations and in contact with relevant outsiders in situations where the construction of social identy becomes specifically relevant for social membership and for gaining access to other social worlds.

3. For an elaboration of our concept of social style and a description of the social style of different social groups in an urban context, see Kallmeyer 1994, Keim 1995, and Schwitalla 1995. For papers and publications of the project on German-Turkish variation, see the research group's homepage (c.f. note 1).

4. In the project on urban communication, these dimensions proved to be most relevant for the construction of a social style and for its analysis; see Kallmeyer 1994, Keim 1995, Schwitalla 1995. Therefore, in our project on migrant youth groups, we started our sociostylistic research with an analysis of these dimensions.

5. For the description of "Gastarbeiterdeutsch", see Klein/Dittmar 1979 and Keim 1984.

6. See the early works on code-switching, e.g., Blom/Gumperz 1972; Poplack 1980; Gumperz 1982.

7. See Myers-Scotton 1993 for the matrix language model which is based upon the assumption that there is always a dominant language.

8. See Grosjean 1982 for the differentiation of bilingual language modes.

9. See Poplack 1987 for the the differentiation of smooth vs. flagged code-switching.

10. Aspects of this language mixture had been analysed in the early studies on codeswitching in terms of borrowing and transfer, and have been recently reconsidered in terms of insertion vs. alternation; see Muyskens 1997; Auer 1998 and 1999.

11. In the transcript, Turkish is in italics; the English translation is enclosed in brackets [...]. For further explications, see the transcription notation at the end of the article.

12. Backus found this pattern in Dutch-Turkish contact situations too, see Backus 1996.

13. As other materials show, Nok is also free to decide what kind of style to use.

\section{References}

Auer, Peter

1998 "Introduction: Bilingual Conversation Revisited". In Code-switching in conversation: Language, interaction and identity, Peter Auer (ed.), 1-24. London / New York: Routledge

1999 "From Code-switching via Language Mixing to Fused Lects: Toward a Dynamic Typology of Bilingual Speech". International Journal of Bilingualism 3 (4): 309-332.

Bakhtin, Michail M.

1986 Speech genres and other late essays. Austin: University of Texas Press. 
Backus, Ad

1996 Two in One: Bilingual Speech of Turkish Immigrants in the Netherlands. Tilburg: Tilburg University Press.

Blom, Jan Petter and Gumperz, John J.

1972 "Social meaning in linguistic structures: Code-switching in Norway". In Directions in Sociolinguistics: The ethnography of communication, John J. Gumperz and Dell H. Hymes (eds), 407-434. New York: Holt, Rinehart and Winston.

Grosjean, François

1982 Life with Two Languages: An Introduction to Bilingualism. Cambridge, Mass.: Harvard Univ. Press.

Gumperz, John J.

1982 Discourse strategies. Cambridge: Cambridge University Press.

Kallmeyer, Werner (ed.)

1994 Kommunikation in der Stadt. Teil 1: Exemplarische Analysen des Sprachverhaltens in Mannheim [Schriften des Instituts für Deutsche Sprache 4.1.]. Berlin / New York: Walter de Gruyter.

Keim, Inken

1984 Untersuchungen zum Deutsch türkischer Arbeiter [Forschungsberichte des Instituts für deutsche Sprache 50]. Tübingen: Narr.

1995 Kommunikation in der Stadt. Teil 3: Kommunikative Stilistik einer sozialen Welt "kleiner Leute" in der Mannheimer Innenstadt. Mit zwei Beiträgen von Werner Kallmeyer [Schriften des Instituts für deutsche Sprache 4.3.]. Berlin / New York: Walter de Gruyter.

Klein, Wolfgang and Dittmar, Norbert

1979 Developing grammars: The Acquisition of German by Foreign Workers. Heidelberg / New York: Springer.

Muysken, Pieter

1997 "Code-switching processes: Alternation, insertion, congruent lexicalization". In Language choices. Conditions, constraints, and consequences, Martin Pütz (ed.), 361-380. Amsterdam/ Philadelphia: Benjamins.

Myers-Scotton, Carol

1993 Duelling languages. Grammatical structure and codeswitching. Oxford: Oxford University Press.

Poplack, Shana

1980 "Sometimes I'll start a sentence in English y termino en español: Toward a typology of code-switching". In Spanisch in the United States: Sociolinguistic Aspects, John Amastea and Lucá Elías-Olivares (eds), 230-263. Cambridge: Cambridge University Press.

1988 "Constrasting patterns of codeswitching in two communities". In Codeswitching: Anthropological an sociolingusitic perspectives, Monica Heller (ed.), 215-244. Berlin: Mouton de Gruyter. 
Schwitalla, Johannes

1995 Kommunikation in der Stadt. Teil 4: Kommunikative Stilistik zweier sozialer Welten in Mannheim-Vogelstang [Schriften des Instituts für deutsche Sprache 4.4.]. Berlin / New York: Walter de Gruyter.

Treffers-Daller, Janine

1998 "Variability in code-switching styles: Turkish-German code-switching paterns". In Code-switching Worldwide, Rodolfo Jacobson (ed.), 176-198. Berlin / New York: Mouton de Gruyter. 